\title{
МОВОЗНАВСТВО
}

\section{ВОЛИНЬ У СИСТЕМІ ЕТНІЧНИХ АВТОСТЕРЕОТИПІВ ЕПІСТОЛЯРНИХ ТЕКСТІВ ЛЕСІ УКРАЇНКИ}

\author{
СВІТЛАНА БОГДАН \\ Східноєвропейський національний університет імені Лесі Українки, Луцьк - Україна \\ bohdan-s@ukr.net; ORCID: 0000-0002-4831-2770
}

\section{ТЕТЯНА ТАРАСЮК}

Східноєвропейський національний університет імені Лесі Українки, Луцьк - Україна taraka2008@ukr.net; ORCID: 0000-0002-2428-447X

\section{VOLYN IN THE SYSTEM OF ETHNIC AUTOSTEREOTYPES IN LESIA UKRAINKA'S EPISTOLARY TEXTS}

\author{
SVITLANA BOHDAN \\ Lesya Ukrainka Eastern European National University, Lutsk — Ukraine \\ TETIANA TARASIUK \\ Lesya Ukrainka Eastern European National University, Lutsk — Ukraine
}

\begin{abstract}
The article explores the peculiarities of the functioning and linguistic actualization of the proper names represented in the system of Lesia Ukrainka's epistolary ethnic autostereotypes. The study has revealed the determinative role of the horonym Volyn and its derivatives волинський, волинська, волинське (volynskyi, volynska, volynske) in the formation of the system and regular use of Volyn astionyms Lutsk, Kovel, comonym Kolodyazhne and katoikonyms volyniaky / volyniaki, volynianochka / volynianka. The article focuses on the comparative analysis of the usage contexts of the nuclear oykonymic names of Volyn and the horonyms of other geographical territories of Ukraine and foreign states, in particular, Germany, Bulgaria and Georgia. The authors argue for the importance of using these names as elements of personal self-identification and a means of linguistic self-portraiture.
\end{abstract}

Keywords: ethnic stereotypes, oykonym, astionym, comonym, katoikonym, Volyn, Lesia Ukrainka. 


\title{
WOŁYŃ W SYSTEMIE ETNICZNYCH AUTOSTEREOTYPÓW EPISTOLARNYCH TEKSTÓW ŁESI UKRAINKI
}

\author{
SVITLANA BOHDAN \\ Wschodnioeuropejski Uniwersytet Narodowy imienia Łesi Ukrainki, Łuck — Ukraina \\ TETIANA TARASIUK \\ Wschodnioeuropejski Uniwersytet Narodowy imienia Łesi Ukrainki, Łuck — Ukraina
}

STRESZCZENIE. W artykule zbadano specyfikę funkcjonowania i aktualizację językową nazw własnych zawartych w systemie epistolarnych autostereotypów etnicznych Łesi Ukrainki; ustalono decydującą rolę w tworzeniu choronimu Wotyń i pochodnych derywatów - wotyński, wołyńska, wołyńskie; określono regulatywność użycia wołyńskich astionimów Łuck, Kowel, komonimu Kołodeżno i katojkonimów Wolyniaky / Wotyniaki, Wolyniaczka / Wolynianka; przeanalizowano porównawcze konteksty użycia jądrowych ojkonimicznych nazw Wołynia i choronimów innych miejscowości geograficznych Ukrainy oraz innych państw, w szczególności Niemiec, Bułgarii i Gruzji; określono ważność używania tych nazw jako elementów własnej tożsamości i środków jej językowego autoportretowania.

Słowa kluczowe: stereotypy etniczne, ojkonim, choronim, astionim, katojkonim, Wołyń, Łesia Ukrainka

$\mathrm{E}$ тнічні стереотипи, що відображають „відносно стійкі уявлення, судження, оцінки тощо представників певної національної лінгвокультурної спільноти про інші (чужі)"” [Бацевич 2007: 37], iї звички, диференційні ознаки поведінки, зовнішності, моральні чесноти, тобто гетеростереотипи, або власне щодо своєї - автостереотипи [Бацевич 2007: 13], належать до регулятивних явищ у семантичній площині будь-якого тексту, що й зумовлює потребу їх активного вивчення в різних функціонально-стильових сферах [Баронин 2000; Сілецький 2008; Скіданова 2009; Чагарина 2015; Черемська, Масло 2011]. Природна й закономірна поява таких одиниць і в епістолярному стилі, який прогнозовано щонайбільше з-поміж інших стильових різновидів актуалізує персональний вимір їх творення (зрозуміло, не без впливу узвичаєних стереотипних уявлень певного етносу).

Епістолярні етнічні автостереотипи Лесі Українки, що відтворюють ії індивідуальні уявлення й міркування про власний народ та рідну землю, сформовані насамперед як результат особистісного досвіду. Такі одиниці закономірно становлять важливу складову їі листовної спадщини. Одним із ядерних 
мовних елементів системи етнічних автостереотипів традиційно вважають власні ойконімійні назви.

Для визначення реєстру таких одиниць в епістолярних текстах Лесі Українки і особливостей формування номінативного поля (зокрема, встановлення продуктивних, малопродуктивних і непродуктивних найменувань) використано метод суцільного вибору мовних одиниць і кількісних підрахунків. Метод контекстного аналізу уможливив пошук варіантів ядерних і периферійних лексем. Завдяки порівняльному аналізу окреслено динаміку / статику вживання ойконімів у межах всього ії епістолярію.

Крім узвичаєного в україномовному узусі хороніма Украӥна (цей номен ужито в збережених листовних текстах Лесі Українки найчастіше - 159 разів (один раз - України-Руси) [Українка 2016; 2017; 2018] (фонетичний варіант Украіна — рідше - лише 12 фіксацій; його використання зумовлене, найімовірніше, різними правописними системами в тогочасній Україні, про що зауважує сама адресантка в одному з листів до Івана Франка: За букву $\underline{\ddot{ }}$ я не стою, але вона має таку саму ращію, як и инші йотовані букви: ю上, я, є і т. д; я стою за правдиву фонетичну правопись (радикальну), але коли тим часом не можу нею друкувати, то вже мушу якось з изією обходитись. Врешті мені щзось теє ̈ㅡ теж спротивилось, можна замінити його йi, або й просто - $i$, напр[иклад], своі, Украіна і т. д. (Колодяжне, 14 (26).V.1892)), вона використовувала водночас і властиві для мовної парадигми кінця XIX-поч. XX ст. номінації Росія / Россія (для тієї частини України, яка перебувала тоді в складі Російської імперії, відповідно вжито персональну ідентифікацію iii мешканців - українці з Росс[і]ї та іронічну самоідентифікацію российская подданая) і підмосковська Україна, Україна російська, прилучена Украӥна, на противагу Австро-Угорщині (до неї входила, зокрема, й частина українських земель), щоправда, саме ця назва не фіксована в їі листовних текстах, натомість використано атрибутивні словосполучення австро-руська література й Австрійська Русь / Австрійська Украӥна та відповідно етнонім - австрійські україниі).

Поряд із основним власним найменуванням у системі ядерних етнічних автостереотипів - Україна - Леся Українка активно вживала також у листах і номінації окремих етнічних регіонів України. Серед фіксованих - Галичина (перифрастична назва - український П'ємонт), Полтавщуина й Буковина. Однак найуживаніші - передбачувано й закономірно - Волинь і Полісся. Саме ці оніми гіпотетично можуть слугувати основою формування всієї системи етнічних автостереотипів їі епістолярію. А тому так важливо простежити їхнє вживання й особливості експлікації.

У всіх збережених епістолярних текстах Лесі Українки топонім Волинь у називному відмінку фіксовано лише тричі (частіше - в інших граматичних 
формах, здебільшого - на Волинь (2), на Волині - (9), з Волині (2), разом 13 разів; один раз щодо Волині вжито номен - Правобережжя), російський варіант Вольнь — тричі (пор. також інші лексеми цього деривативного ряду: волинський - 17 разів, волиньський — 5 разів, вольнский — двічі (у назві статті Олени Пчілки Украинские колядки (текст волынский)), волынская (в поєднанні з лексемою губернія (в адресі) - 1 раз), неволинські - (1); катойконіми волиняки - (1) / волинякі - (1), волинянка-(1), волинячка - (1)). Привертає увагу використання двох варіантів відтопонімічних означень: волинський і волиньський (щоправда, рідше, ніж перший варіант, наприклад: хата волиньська; волиньські пісні і волинський діалект), пор. також: новоградволиньске. Передумови варіантності такого написання в текстах Лесі Українки навряд чи можна пояснити технічними недоглядами авторки (з огляду на спонтанність епістолярної комунікації), а радше неусталеністю тогочасних правописних норм української мови.

Номен Полісся (проєктований у листах Лесі Українки властиво на Волинське Полісся) вжито також лише тричі, поліський - шість разів, катойконім полішук / полішуки - двічі.

3-поміж найочікуваніших регулятивів цього лексико-семантичного поля фіксовано й інші ойконімійні назви Волині — астіоніми Луичк (10) / Луичкъ (1) (луцьккий (1)); Новоградволинськ (1) / Новоградвольнскк (1); Ковель (16) (до речі, послідовно вжито граматичні форми з / до Ковля на противагу сучасній нормі - з / до Ковеля) (деривати — ковельський (1), ковельське (2), ковельско (1), катойконім ковельчани (1)); комонім Колодяжне (106) (найпродуктивніший номен), (похідні назви - колодяжанський / колодяжсанські (3), колодяжаньска - (1), по колодяжсанськи (1)).

Релевантно до ядерних найменувань вжито також лексеми, що належать до периферійних у цьому лексико-семантичному полі: астіонім Звягель (саме тут, як відомо, народилася Леся Українка 1871року), перифрастично названий нею Schöne Wiege meiner Leiden („Прекрасна колиска моїх страждань” (нім.) - цитата з Г. Гейне), сучасний Новоград-Волинський (1), (звягельська (1)), комоніми - Любитів (1), Запруддя (11) (запрудських (1)), Жабориия (1), Тагачин (2); лімнонім Нечімне (1) / Нечімнеє (1) (інші, не фіксовані в епістолярію назви цього озера, - Нечимне, Нечімле).

Регулятивний характер найуживаніших топонімів у листах має реальне підгрунтя. Використання цих онімів зумовлене насамперед потребою локальних характеристик місць перебування адресантки. Йдеться насамперед про номінації Волинь, Полісся, Луцьк, Ковель і щонайчастіше - Колодяжне. Саме в Колодяжному Леся Українка з-поміж усіх українських місцин мешкала якнайдовше. Як відомо, сюди Косачі приїхали в травні 1882 року. Востаннє вона була в Колодяжному в лютому 1907 року. Сама Леся Українка, за твердженням сестри Ольги, вважала його своєю “єдиною домою”, „з ним пов’язано найкра- 
щі спогади про дитячі та юнацькі роки поетеси, тут була їі творча «майстерня» — «білий» будиночок, де написано чимало геніальних творів” [Українка 2016: 4] (хоча безпосередньо в Лесиних епістолярних текстах саме таке зізнання відсутнє, на противагу іншим членам родини Косачів, зокрема, братові Михайлу: Домівка настояща властива для мене, принаймні по тому почуттю, яке зв'язане з иим словом, лише в Колодяжному. Колодяжне - оце власне „дома”, а решта, то ие все так собі - межи іншим (до матері, 19.02.1897) [Косач 2018]. Власне цим щонайперше і мотивоване частотне використання цієї лексеми як одного з продуктивних топосів іï епістолярних діалогів. Однак, цей чинник хоч і був важливим, але все ж не його, очевидно, варто вважати визначальним. Для Лесі (і не лише для неї, а й для інших Косачевих дітей, зокрема для Михайла) са́ме Колодяжне і Волинь слугували синонімом рідного дому, точніше кажучи - доми (СУМ подає це слово в першому значенні в узуальному використанні як прислівник: „дома присл. Те саме, що вдома” [Словник української мови 1971: 361], іменникове значення — $з$ ремаркою розмовне: „розм. Те саме, що домівка”); натомість саме лексему дома — цей західнополіський діалектизм - вона послідовно вживала в епістолярному спілкуванні з батьками, з братами-сестрами для номінації Косачівської домівки саме в Колодяжному; очевидно, не лише в епістолярному, і не лише вона, а й інші члени родини, як засвідчує їхня збережена епістолярна спадщина [Українка 2016, 2017, 2018; Кочерга 2003; Косач 2018] й спогади [Спогади про Лесю Українку 2017].

Вживаючи цю лексему поза звичним “колодяжсанським” контекстом, Леся Українка використовує графічний маркер — лапки, імплікуючи, очевидно, в таких випадках відсутність властивої для цієї номінації семи 'рідна', як-от у згадці про дому в Кутаїсі: Так отже „пуф” якийсь ув'язався! Правда, я його десь ще їучи кіньми захопила, бо ще тоді стало мені погано $і$ в Тiфлісі через те про світолічення не розпиталась, хотіла вже якось дойхати до нової „доми” (тут і далі вирізнення наше. - С. Б., Т. Т.), бо почувала, щцо ледве держуся (до Косач О. П. (матері), Кутаїсі, 30.X (12.XI).1910). А тому для Лесі Українки саме Волинь (і щонайперше - Колодяжнне - $з$ інтимізуючим означенням наше: Побачили б наше Колодяжне, може, вам і гарне воно здасться (до Драгоманової Є. І., Колодяжне, кінець грудня 1888 - початок січня 1889 р.)) - узвичаєно асоціат доми, рідного краю, про що стверджує передусім ії відомий афоризм зі стилістично окресленим тавтологічним компонентом найрідніший рідний та епітетом властивий, тобто органічний, природний: Властивий, найрідніший рідний край для мене - Волинь, туди мені [не] можна, а Київ і Полтавщина для мене однакова Украйна (до Косач О. П. (матері), Ялта, 22.III (3.IV).1898)).

Парадоксальність ситуації полягала в неможливості поєднати й гармонізувати в іiї особистісному вимірі дві модальні категорії хочу й можу щодо 
перебування на Волині. Для Лесі Українки вони завжди створювали виразну бінарну опозицію в ситуації, зокрема, з Колодяжним: бажання жити тут дисонувало з неможливістю перебувати через несприятливі для її здоров'я кліматичні умови: В Колодяжне я все таки не одважуюсь їхать, хоч може се і неосновательно на твою думку. Скажу тілько, що всі мої хірурги не хвалили Полісся (йдеться власне про Колодяжне. - С. Б., Т. Т.) для життя людей з туберкульозом хоч би й такої форми, як у мене (до Косача П. А., Ялта, 22.V (4.VI).1898). Як бачимо, оцінка Колодяжного в цьому контексті має не крайній вияв категоричності, бо актуалізовано іiі радше через несприйняття Полісся як місця особистісного перебування. Порівняймо інші подібні емоційно фрагменти: В Колодяжне їхати просто з Криму я боюся, бо там мені завжді був страх від малярійного бацила» (до Косач О. П. (матері), Ялта, 10 (22).III.1898); В Колодяжне кликав мене папа, та я туди побоялась їхать, щоб знов малярія не вхопила, - було б се не дуже до речі (до Драгоманової Л. М., Гадяч, 18 (30).VI.1898); Напиши в Черн[івиі], чі довго будете в Колод[яжному], — може мені вже просто в Гад[яч] їхати? Але скілька день в Колод[яжному] я б з охотою побула (довго боюся), я вже давно там не бувала (до Косач О. П. (сестри), Кимполунг, 13 (26).VI.1901)).

Власне тому семантичний простір контекстів уживання цього топоніма дуже часто сконструйований в модальних координатах хочу - не можу, що актуалізує здебільшого емоційні стани страх, боязнь, про що свідчить і експлікація лексем цього синонімічного ряду: страх, побоялася, боюся. Цей синонімічний ряд проєктований, до речі, на клімат усього Волинського Полісся, порівняймо: Лілі я тепера не пищу, хоч ї̈ одкриточки отримала, бо не знаю, чи в Києві вона тепер, чи вже може в Тагачині (Ольга Косач на той час клопоталася про призначення на посаду лікаря в село Тагачин, поблизу Колодяжного (нині - Турійський район, Волинська обл. — прим.)). Коли б то там Михальові не заваділо в наших поліських сторонах —боюся я того клімату! (до Косач О. П. (матері), Ялта, 3 (16).ІІ.1908).

Асоціативно маркер негації експліковано також в словосполученні полісь-

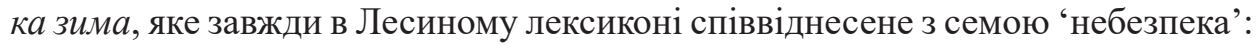
Тілько зо страхом думаю, щяо буде зо мною в зимі? Чи не знищить та зима знову всього, придбаного за літо, як уже не раз нищила? Та ще наша поліська зима, мокра та льодовата, - ой, ой, боюся!.. (до Драгоманова М. П., Крим, Свпаторія, 16 (28).VII.1891). Такі ж асоціації згадана особливість Полісся зберігає і в інших контекстах, пор.: Дарма, хоч тая „весна” по осінньому процвіла, може б літом надолужила. Але то щьо року такі марні надії, поки літо, а прийде зима наша поліська, та й знов я починаю гинути помаленьку (до Павлика М. I., Свпаторія, 16 (28).VII.1891). Цей асоціативний ряд продовжують також інші словосполучення з тією ж атрибутивною ознакою, наприклад: поліські тумани (...і я, на який час переӥхала в Бесарабію, щоб до 
дому було близще і щоб все-таки не бути серед поліських туманів осінніх (до Драгоманова М. П., Шабо, 22.VIII (3.IX).1891).

Щоправда, як стверджує в одному з листів адресантка, іiї перестороги й сумніви нерідко не поділяли деякі члени родини, зокрема, батько: Се ж тілько папа не хоче „уступить позицї” і шо дня запевняс мене, щзо тут , климат как климат, никакой маляріи - обыкновеннъйшая простудная лихорадка, как вездъ и у всьх, кто не бережется" і шо К[льоня] (Климент Квітка. - С. Б., Т. Т.) ,, прекрасно” міг би пробути тут „всю весну”. Але ж я, звичайне, такого оптимізму мати не можу... (до Косач О. П. (сестри), Колодяжне, 23.II (8.III).1907). і значно рідше фіксуємо звичайний бажальний модус: Буду в Києві коло 5-го іюня ст. ст. Хотіла б і в Колодяжне заглянуть (до Косач О. П. (сестри), Тбілісі, 24.V (6.VI).1905). Цими пресупозитивними передумовами й мотивована поява в епістолярію як стереотипного відомого метафоричного регулятива щодо Волинського Полісся — вічно плачушче небо (Правда, щзо у нас тепер спека надзвичайна, надто для Полісся, щзо звикло до вічно плачушчого неба (до подружжя Драгоманових, Колодяжне, 18.VIII.1892)).

Не є випадковим і те, що саме епістолярні згадки Лесі Українки про Волинь завжди мають ностальгійний вимір із огляду на їі "мандрівний триб” життя, а тому лексема дома визначальна у формуванні концептуального поля рідна “земля” на противагу “чужина”, що й зумовлює формування в ії епістолярних текстах частотних опозитних пар: Волинь - різні топоніми з семантичного простору “чуже”. До них належать, зокрема, номінації міст: кримських, болгарських, німецьких та грузинських. Іноді такі контексти мають зіставний характер без конкретної актуалізації й симетричного відображення власних найменувань, як-от: болгарські гори - Волинь, Київ (Тілько й досі мені часами здається, що я бачу у сні і Ліду, і Раду, і сі гори болгарські зелені, що у сні я бачила й дядька з дядиною, що я прокинуся от-от де небудь на Волині, чі в Київі і все зникне, тілько жаль зостанеться (до Павлика М. І., Владая, 1 (13).VIII.1894)).

Спостережено й інший, особливий вектор таких порівняльно-зіставних контекстів: саме чужоземні реалії найчастіше слугують асоціатами рідного простору: Шварцвальд (Німеччина) — Волинь (... в Шварцвальді, як і взагалі в Німечині така сама сухість, як у нас на Волині. Уже коли шукати сухости, то скоріш ії можна найти, напр [иклад], в Тіфліських горах, а теплости скрізь на Кавказі „хоть одбавляй” - то чого б се я погналась у Німеччину? (до Косач О. П. (сестри), Хелуан, 7 (20).IV.1911)); Кавказ - Волинь, Полісся (Зрештою, на Кавказі сам чорт не розбере, де та малярія єсть, а де ї̈ нема, тут про се так само трудно допитатись, як про те, з которого села на Волині починається Полісся (до Косач О. П. (сестри), Тбілісі, 9 (22).IV.1904)); Хоні-Колодяжне (Хоні трошки , трущобка”, але нічого собі - багато садків, просторі зелені двори, гори на горизонті, хоч само воно рівне як Рівне, або 
як Колодяжне. Нагадує Колодяжне і те шосе, що провадить сюди з Кутаіса, бо по обидва боки глибокі рови, та й в самому Хоні багато ровів і колодязів. Словом - кавказське велике Колодяжне (має 30 квадр [атних] верстов) (до Косач О. П. (сестри), Хоні, 5 (18).IX.1911)); Телаві-Луцьк (замки) (В самому Телаві багато руїн старосвітських (це колись була столиия иарів Кахетії), посеред міста иіле замчище з вежами з зубчастими мурами (Йдеться про замок царя Грузії Іраклія II „Батоніс-цихе” (XVII ст.)), воно мені нагадує Луцький замок і моє „отрочество”... (до Комарової Г. М., Телаві, 10 (23).III.1909)).

Почасти в опозитиві вербалізовано лише один елемент бінома, а інший представлений узагальненими найменуваннями або позбавлений конкретного вияву, наприклад, Волинь - инші краї: Та щуе в нас на Волині людям не лихо жити, бо голоду нема, навпаки, ліпше маємось ніж другі. Але слухаючи та читаючи, що робиться по инших краях, то дуже тяжко і страшно робиться (до Павлика М. І., Колодяжне, 5 (17).XII.1891).

Опозитні пари фіксовані також у межах власне українського простору: Ялта - Полісся, Колодяжне (Шкода, що ти не могла пойхати зо мною, як раз от тепер і не гаряче, сливе так як в Колодяжному, тілько без вільгости (до Косач О. П. (сестри), Ялта, 20.VI (2.VII).1897)); Крим - Гадяч, Волинь (Я до літа поправлюсь і вже не поїду в Крим, а будуз вами жить де небудь в Гадячі, або на Волині - j’ai bien mérité cela (Я це цілком заслужила (франц.)) (до Драгоманової А. М., Ялта, 7 (19).XI.1897)). Як бачимо, позитивний вектор таких зіставлень завжди був скерований в одному напрямі - Волинь.

Типовими для листів Лесі Українки можна вважати й ті порівняльно-зіставні контексти, що представлені трьома компонентами, обов'язковим у яких є “волинський” сегмент, як-от в описі Чернівців: Чернівці-Волинь - Київ: Місто не дуже велике, багато менше ніж Львів і провінціальніше, але симпатичне i чистеньке, иіле на горі, околиия дуже гарна, якась ідилічна: гори ще не дуже високі, не вищі від волинських (в дубенській околиці), або й від київських (може, правда, трохи вищі), Прут під самими Чернівиями тихий, в зелених берегах, в 'ється собі поміж гаями по широких „зарінках” (до родини Косачів, Чернівці, 15 (28).IV.1901).

В одному з цитованих вище листів із Грузії актуалізовано відому дискусію часів Лесі Українки про те, де на Волині розпочинається Полісся. До речі, дотепер навіть на Волинському Поліссі можна почути категоричні твердження діалектоносіїв, що деякі мовні говіркові реалії варто шукати не в них, а на Поліссі: у такий спосіб експліковано виразний маркер меншовартості щодо цього регіону на противагу іншим, зокрема, й волинським. Леся Українка використовує відомий стереотипний вираз у властивому іï ідіолекту порівняльному контексті: Зрештою, на Кавказі сам чорт не розбере, де та малярія єсть, а де іï нема, тут про се так само трудно допитатись, як про те, з которого села на Волині починається Полісся (до Косач О. П. (сестри), Тбілісі, 9 (22).IV.1904). 
У цьому фрагменті номен Полісся позбавлений стилістичного забарвлення. На противагу йому інші фіксації цього топоніма слугують ствердженням майже регулярного негативного маркера, актуалізованого внаслідок руйнівного впливу клімату цього регіону на здоров’я Лесі Українки, зокрема, через вологість і нечастотність сонячних днів. А тому рідкісні нетипові сонячні дні на Поліссі сприймалися нею радше як анорматив, що відтворено згаданим персоніфікованим висловом „, вічно плачущого неба” (до подружжя Драгоманових, Колодяжне, 18.VIII.1892). Саме ці несприятливі умови, як відомо, змушували Лею Українку постійно шукати сухого й сонячного клімату: спочатку — в Криму, пізніше - в Італії, в Сгипті та на Кавказі. Власне вони слугували передумовою появи типових оцінювальних контекстів щодо Полісся.

Поліські реалії (природа, люди) нерідко виступають в листах асоціатами іншого, “чужого" простору, як-от: кипариси - сосни (3 твойм виїздом виїхала від нас і погода: другий день без перестанку йде сніг, не снігодощ, а таки сніг, як слід, аж кипариси погнулись під важким „на́вісом”, наче поліські сосни. Мені шкода, щуо ти не бачиш сього видовиська - се дуже оригінально (до Косач О. П. (матері), Ялта, 13 (25).І.1898); болгари - поліщуки (...взагалі болгаре скорости не люблять, як і наші полішуки... (до Косач О. П. (сестри), Софія, 19.XII.1894).

Іноді такі порівняння мають імпліцитний вияв у семантичній структурі метафоричних сполук, як-от: волинські нідерланди (Але як не судиться в загранічні, то треба вже хоч у Гадяцькі гори їхати, а то в наших волинських нідерландах дуже вже плаксивий клімат) (до Драгоманова М. П., Київ, 5 (17). IV.1894). У цьому фрагменті Волинь і Нідерланди уподібнені на основі семи 'вологість', що стосується характеристики клімату. Водночас Волинь виступає опозитом Гадяча, що вирізнявся сухішим кліматом.

Зафіксовані в епістолярних текстах атрибутиви волинський, поліський $i$ колодяжанський стосуються різних аспектів побуту, явищ, подій, творів тощо, наприклад: волинське життя (Роїться мені в думиі скілька тем - $і$ з боротьби християнства з „,релітією предків мойх”, $і$ з часів татарських наскоків (баладний мотив про брата і сестру), і з цеехового волинського життя, вабить мене образ Костя Гордієнка (не так його самого, як подібного до нього) (до Кримського А. Ю., Кутаїсі, 24.V (6.VI).1912)); волинський діалект (Говорила вона спочатку, як то звичайне, ламаною московщиною, а тепер уже перейшла зовсім на дуже правильний волинський діалект і тілько коли-не-коли „закидає” по московськи, та певне й се недовго буде (до Косач О. П. (матері), Київ, 19.IX (2.X).1906)); волинська фантазія (Волинська фантазія мала найбільший успіх (хай радується Ваша остріжська душа!) (до Кривинюка М. В., Чернівці, 15 (28).IV.1901); волинських „баллад” (На пробу Міма оце мусить Вам послати скілька волинських „баллад”, щуо я йому диктовала» (до Драгоманова М. П., Крим, Свпаторія, 16 (28).VII.1891)); 
Волинська Літопись (Мені здається, щуо якби я сама прочитала якусь там Волинську Літопись чи Самовидия, то я б там вичитала щось таке, чого мені бракує у сучасних істориків (не виключаючи і Грушевського), а потім, може, й сказала б щось таке, чого ще не казали инші наші поети (до Кримського А. Ю., Кутаїсі, 24.V (6.VI).1912)); Волынский Съђзд (Предсьдателю Ковельско-Владиміръ-Волынскаго Мирового Съђзда въ деревню Колодяжно (до Маковея О. С., Київ, 17 (30).І.1907)).

Такі атрибутивні словосполучення, крім типологічних узвичаєних функцій, часто слугують, як бачимо, засобом автопортретування адресантки. До індивідуально окреслених і стилістично увиразнених безперечно належить конструкція волинські ліси, яка асоціативно в українському культурному соціумі пов'язана саме з особистістю Лесі Українки, з її Лісовою піснею. Коментуючи в листі до Агатангела Кримського чинники появи цього твору, вона, зокрема, зазначала: Треба було в Сгипті вродитись, то може й був би лад, але ж найгірша помилка мого життя - се що я зросла у волинських лісах, решта все тілько логічні наслідки. А про те я не згадую лихом волинських лісів. Сього літа, згадавши про їх, написала „драму-феерію” на честь їм, і вона дала мені багато радощів, хоч я й відхорувала за неї (без сього вже не йде!) (Хоні, 14(27).Х.1911) (пор. фрагмент листа до матері: Мені здається, щзо я просто згадала наші ліси та затужила за ними) (до Косач О. П. (матері), Хоні, 20.XII.1911 (2.I.1912)). Авторський коментар у цитованих листах слугує водночас джерелом декодування особливої прихильності Лесі Українки до волинських лісів, незважаючи на те, що саме вони спричиняли дисгармонію в її побутуванні на Волині.

Щонайбільше характеризує особистість адресантки вислів спеціально волинська вдача, яка була, на їі переконання, домінантою в характері: ...маю надто українську, а навіть спеціально волинську вдачу $i$ часто, боячись показати себе не в пору експансивною, попадаю в инший гріх - здаюсь індиферентною (до Кобилянської О. Ю., Берлін, 8 (20).V.1899).

Як елемент портретування Лесі Українки використано також атрибутив новоградволинське в поєднанні з номеном жабенятко. Ця оцінна номінація експлікована в листовному тексті як інтертекстуальна і виконує апелятивну функцію. Ї̈̈ автором був дядько Михайло Драгоманов: ...дядько нас вітає: ,, $a$, здрастуйте, жаби!” (Жаба - слово не „уничижительное”, а „ласкательное”, я часом буваю удостоєна епітету „жабинятко новоградволиньске”) (до Косач О. П. (сестри), Софія, 19.XII.1894).

Актуалізація словосполучення волинські школи дає можливість реконструювати автостереотипні міркування Лесі Українки про волинян, зокрема, щодо їхніх розумових здібностей на противагу недосконалості тодішньої шкільної освіти: Але я думаю, щь наші люди з натури дуже розумні, бо їх на- 
віть наші волинські школи не можуть дурнями зробити, а вже, здається, для сього не мало прикладається роботи (до Драгоманова М. П., 15 (27).Х.1892).

Атрибутивне словосполучення волинська хата вжито в контексті повідомлення Іванові Франку про завершення роботи над етнографічним описом волинської (поліської) хати (очевидно, на його прохання): Описання хати волинської (а власне поліської намої) я Вам хутко пришлю (11 (23).Х.1893).

Спорадично фіксовано використання як абсолютних синонімів атрибутивів волинський / правобережний: Перша пісня (Ой у полі корчомка) має типічний волинський (чи взагалі правобережний) мотив (до Драгоманова М. П., Колодяжне, 21.XII.1891 (2.I.1892)).

Прикметна деталь епістолярію Лесі Українки: Волинь у іï листах часто вжито в широкому, історичному контексті: Про галицьких емігрантів я чула таке, ніби їх з осени найшло чимало до натих волинських міст, напр [иклад], до Кремения, Острога, тинялися вони там цілими гуртами, шукаючи роботи, та збиваючи плату нашим робітникам, бо голодному галичанинові що хто хотів, те й давав (до Драгоманова М. П., 10 (22).XII.1892).

Урочисто-величальний контекст має одна з актуалізацій топоніма Луцьк, у якому йдеться про можливий приїзд до нього Л. Черняхівської-Старицької: Люді Луик перстом Божим указаний! таки єсть якась Немезіда на світі. Тепер як хто куди не бажатиме попасти, то нехай не описує à priori, бо ще якраз попаде! (до батьків, Сан-Ремо, 25.XII.1902 (7.I.1903)).

Волинь, Колодяжне - це ще й люди, звичаї, традиції, пісенна культуpa, мова. Емоційний стан Лесі України в час перебування в Колодяжному (а саме в ньому, за її зізнанням, вона почувалася найкомфортніше: нігде так не добре, як вдома (до Павлика М. І., Колодяжне, 1 (13).Х.1891)) найповніше відтворюють кваліфікативи, як-от: живе діло і милі люде , які виступають домінувальними ознаками ії побуту тут: Тепер я вдома і се добре, бо хоч тут мене таки ззість колись пропасниия, але мені нігде так не добре як вдома і робота тут найліпше робиться. Та ще ж тут і окрім писання є живе діло i милі для мене люде, тут не почуваю себе зайвою на світі. От тілько від товариства далеко, ну та воно обійдеться без мене краще, ніж я без ёго (до Павлика М. І., Колодяжне, 1 (13).Х.1891). Семантично релевантний вимір має й оцінна характеристика колодяженців - привітні люди, актуалізована в зіставному контексті з болгарами, порівняймо: ...завтра їду в Київ, то треба збиратись. Мама тепер тут, а я на який час поїду на ї місие туди - мені вже пора, треба дещо. Довго, впрочім, не думаю бути, мені тепер ліпше тут, ніж у Києві (...). Справді мені здається, що у нас таки люди привітніші, ніж у Болгарії, чи, може, я мало знаю болгар? Шкода справді мені кидати Колодяжне, але ж і в Київ треба (до Драгоманових, Колодяжне, 9 (21).Х.1895). Найбільш виразно ії ставлення до односельчан характеризує епітет любi в од- 
ній із прощальних формул: Бажаю щастя-долі усім любим колодяжсаниям (до Косач О. П., Свпаторія, 23.VI (5.VII).1891).

Леся Українка часто згадує в листах різні колодяженські події, побут мешканців цього населеного пункту (це дає можливість частково реконструювати подієву парадигму кінця XIX - поч. XX ст.), людей. Наприклад: Въ Колодяжному тепер шкарлатинъ (до Драгоманової С. І., [Луцьк], 2 (14).I.1881); Казала Каролька, що Марисі чоловік вже не б'є, бо соромиться сусідів „делікатніших" (вони живуть тепер серед вокзальних майстрів), і що він збірається будувати власну хату. Катерині Філаретовій (Ратманова Катерина Філаретівна - куховарка Косачів у Колодяжному, їх служниця протягом 1893-1900 років. - прим.) зле ведеться, бо ї̈ чоловік під судом за убійство сусіда (побились через сварку між жінками) а син (старший хлопчик) недавно вмер, провалившись в холодну баюру і схопивши якусь гостру застуду (слабував усього три дні). Весілля колодяжанські вже покінчились і Варка (В. Й. Дмитрук-Пиріг. прим.) зовсім охрипла після них - переспівалась (до Косач О. П. (сестри), Колодяжне, 23.II (8.III).1907); Про новини Колодяжанські напишу, коли хоч трохи заспокоюсь - тепер я наче маніак, все про одно думаю. Новин, правда, мало. Два весілля, з них одно Тимошеве - брата Варчиного — з Старшинівною (до Косач О. П. (сестри), Колодяжне, 18.ІІ (3.III).1907).

Закономірно поетеса цікавиться передусім тими персоналіями, з якими мала найтісніші безпосередні та опосередковані контакти (це, зокрема, Boскресенські (знайомі Косачів з Волині), Карташевські (Микола Петрович Карташевський, голова Ковельського з'їзду мирових посередників; Марія Миколаївна Карташевська, хрещена мати Миколи Косача. — прим.), ковельський лікар Левіџький / М. I. Левицький, студент Скиба (Скиба - студент Варшавського університету, син начальника залізничної станції м. Ковеля, приятель Миколи Косача. - прим.); Володя Просяниченко (Просяниченко Володимир Антонович - найближчий приятель Миколи Косача, друг родини, після смерті П. А. Косача управитель маєтку в Колодяжному. — прим.), Кароль (Русинович Кароль Робертович — управитель маєтку в Колодяжному, народний майстер-тесляр, будував дім Косачів у Зеленому Гаю. — прим.) тощо).

Спостережено: Леся Українка паралельно використовувала два варіанти назви мешканців Волині - волиняки (до Косач О. П. (матері), Хоні, кінець грудня 1911 (початок січня 1912) року) і фонетичний варіант волинякі, первинніший у їі ідіолекті з огляду на часову фіксацію (до Драгоманова М. П., Київ, 5 (17).IV.1894). Водночас вона вживала й два лексичні варіанти етнонімічних найменувань жінок — волинячка (... хор співав „Гей не дивуйте”, співачка Снарская (наша волинячка) — „Чом, чом чорнобров”, а в самому кінці хор утяв „Ср[б]ия свободна” (Ще не вмерла Украіна)) (до Косач О. П. (матері), Київ, 20.ІІ (4.ІІІ).1890)) і волинянка (Фрося волинянка, близька землячка і су- 
сідка Варчина (до Косач О. П. (матері), Київ, 19.IX (2.X).1906)). Етнонімічні назви чоловіків із Волині не фіксовані в її епістолярних текстах.

Неодноразово Леся Українка актуалізує в листах із різним функційним навантаженням стереотипні вислови колодяженців і волинян, подаючи їх найчастіше як цитати з вказівкою / без вказівки на адресата / адресатів. До таких висловів здебільшого належать: як не може бути (усічений варіант первинного - усе, як не може бути добре) і синонімічний вислів слава Богу, нічого нового, нічого не наслучалось та його усічені варіанти нічого нового, слава Богу / слава Богу, нічого нового (фіксовано 11 разів). Наприклад: Не знаю, чому не пите мама до Вас, я на неї нападуся за це дуже, як приїу до дому. Вона нам часто пише із листів видно, що у них все гаразд ,як не може бути", мовляли наші волинякі (до Драгоманова М. П., Київ, 5 (17).IV.1894); Ти досі вже отримала мого великого листа - з того часу нічого „не наслучалося" (слава Богу, кажуть волиняки) (до Косач О. П. (матері), Хоні, кінець грудня 1911 (початок січня 1912) року); Більще, „слава Богу, нічого нового” (до Косач О. П., Київ, 4 (16).ІІІ.1896); Думаю, щзо треба врешті щзось написати тобі про себе - а то знов вийшло „взгляд и ньчто” замість листа - $і$ не знаю що: слава Богу, нічого нового!.. (до Косач О. П. (матері), Ялта, 23.IX (5.X).1897); У нас в хаті, „слава Богу, нічого нового”, — велика хата все не зайнята і там спить Настя (до Косач О. П. (матері), Ялта, 21.ІІ (5.III).1898); „Слава Богу, нічого нового ”... (до Косач О. П. (матері), Ялта, 19.IV (1.V).1898); В нас нічого нового „слава Богу” нема, всі в доброму здоров '̈̈ (до Косач О. П. (матері), Київ, 13 (25).Х.1898); У нас, слава Богу, нічого нового, нічого не наслучалось за сей час (до Косач О. П. (матері), Гадяч, 24.VIII (5.IX).1899); Hy, сяк чи так, у нас хоч „слава Богу, нічого нового” (до родини Косачів, Телаві, 31.III (13.IV).1909); Дома, ,слава Богу, нічого нового” (до Косач О. П. (матері), Київ, 8 (21).V.1911); Що ж би про нас написати? ,Слава Богу, нічого нового” (до Косач О. П. (матері), Кутаїсі, 29.VI (12.VII).1912); Про иншу „матерію” можна сказати: ,„слава Богу, нічого нового”, себто t рідко нормальна (до Косач О. П. (сестри), Кутаїсі, 26.VII (8.VIII).1912). Як бачимо, інтертекстуальний статус другого варіанта цього вислову нерідко сигналізує лапковий маркер.

Спорадично актуалізовано в листах і стереотипний колодяженський вислів ,,то ж то сума́” (Отож, значить, мені треба 700 р[ублів] забезпечених, щоб прожити місяиів 4 в Сгипті (а з місяиь піде на переїз) — „то ж то сума́!” говорячи по колодяжанськи....) (до Косач О. П. (сестри), Кутаїсі, 20.IX (3.X).1912)). Такі узвичаєні й стереотипні говіркові вислови найчастіше вжито (зі зрозумілих причин!) в основному в родинному епістолярному спілкуванні.

Саме тут, у Колодяжному, Леся Українка записала пісні, що ввійшли до іiі відомої збірки - Колодяженського зошита (до речі, і Леся Українка, і іiі сестра Ольга називали його „Колодяжсанським збірником” (див. лист до Косач 
О.П. (матері), Кутаїсі, 29.VI (12.VII).1912 ) та примітку в листі до Кривинюка М. В., Чукурлар, середина червня (кінець червня за н. ст.)), а 3-поміж них - 54 особливих пісенних текстів, поширених в основному на Волинському Поліссі, - “танцюристі пісні”: Оие надумую видати маленький збірничок таниюристих пісень народніх (бачте, як розвеселилась?) для народа ж. Мають туди увійти переважно волинські пісні, до яких мелодії я попросила записати п. Квітку (до Франка I. Я., Тбілісі, 15 (28).XI.1904).

Аналіз особливостей уживання власних назв, що входять до ядерних одиниць епістолярних автостереотипів Лесі Українки, показує регулятивність уживання й багатофунційність статусу. Крім хороніма Україна, в іiі епістолярних текстах фіксовано регулярне використання назв окремих етнографічних частин - Полтавщина, Буковина, Галичина, Волинь. Кількісні параметри листовної актуалізації назви Волинь, хоч і не $є$ найчастотнішими, однак контексти їхнього вживання переконливо стверджують виняткову роль саме цієї частини українського простору в системі автостереотипів адресантки. Найвиразнішими вербалізаторами мовного образу Волині слугують топоніми Луцьк, Ковель і Колодяжне (село, в якому вона проживала найдовше з усіх українських міст і сіл, саме його Леся Українка вважала “єдиною домою”, тобто найбільш дорогою й рідною місциною з-поміж усіх інших). А отже, саме лексема Колодяэне й похідні від неї утворення безперечно належить до ядра лексико-семантичного поля найменувань цього етнографічного регіону Волині. Спостережено виняткову роль онімів Волинь і Колодяжне як елементів особистісної ідентифікації й автопортретування адресантки.

\section{Список використаної літератури}

Баронин А., Этническая психология, Киев: ПК ООО „Тандем”, 2000.

Бацевич Ф , Словник термінів лінгвокультурної комунікації, Київ: Довіра, 2007.

Колодяженські пісні з рукописного зошита в записах Лесі Украйнки та Ольги Косач, Луцьк: Волинська обласна друкарня, 2006.

Косач М., Твори. Переклади. Листи. Записи кобзарських дум, Київ: Видавничий Дім „Комора", 2018.

Крысько В., Сочиальная психология: словарь-справочник, Москва: АСТ, 2001.

„Листи так довго йдуть...”: знадоби архіву Лесі Українки в Слов 'янській бібліотеиі у Празі, упоряд., передмова та прим. С. Кочерги, Київ: Просвіта, 2003.

Селіванова О., Сучасна лінгвістика: термінологічна енщиклопедія, Полтава: Довкілля, 2006.

Сілецький Ю., Росіяни в етнічних стереотипах украӥнців (на матеріалах українського традиційного світогляду), [в:] „Науковий часопис Національного педагогічного університету імені М. П. Драгоманова. Серія: Історичні науки”, 2008, вип. 6, с. 382-393. 
Скіданова К., Етнічні стереотипи як складові мовної картини світу, [в:] „Наукові записки. Серія: Філологічні науки", 2009, вип. 81 (4), с. 27-31.

Словник української мови, в 11 томах, ред. І.К. Білодід, Київ: Наукова думка, 1970-1980, т. $1-11$.

Словник украӥнської ономастичної термінологї, уклад. Д. Г. Бучко, Н. В. Ткачова, Харків: Ранок - НТ, 2012.

Спогади про Лесю Українку, уклад. Т. Скрипка, т. 1, Київ: Темпора, 2017.

Чагарина С., Етнічні стереотипи в уявленні студентів-украӥнців м. Луцька, [в:] Електронний pecypc: https://sp-sciences.io.ua/s2295702/chaharna_svitlana_2015._ethnic_stereo (01.07.2019).

Черемська О., Масло О., Лінгво-етнічні стереотипи української народної казки, [в:] „Культура народов Причерноморья: научный журнал”, 2011, № 211, с. 113-115.

\section{Список використаних джерел}

Леся Українка, Листи: 1876-1897, упоряд. В. А. Прокіп (Савчук), передмова В. П. Агеєвої, Київ: Комора, 2016.

Леся Українка, Листи: 1898-1902, упоряд. В. А. Прокіп (Савчук), Київ: Комора, 2017.

Леся Українка, Листи: 1903-1913, упоряд. В. А. Прокіп (Савчук), Київ: Комора, 2018.

\section{Spysok wykorystanoi literatury [References]}

Baronin A., Jetnicheskaja psihologija [Ethnic Psychology], Kiev: PK OOO „Tandem”, 2000.

Batsevych F., Slovnyi terminiv linhvokulturnoi komunikatsii [Glossary of Terms for Linguistic and Cultural Communication], Kyiv: Dovira, 2007.

Kolodiazhenski pisni z rukopysnoho zoshyta v zapysakh Lesi Ukrainky ta Olhy Kosach [Kholodiazhenski Songs from a Handwritten Notebook in the Recordings of Lesia Ukrainka and Olha Kosach], Lutsk: Volynska oblasna drukarnia, 2006.

Kosach M., Tvory. Pereklady. Lysty. Zapysy kobzarskykh dum [Works.Translations.Letters. Records of the Kobzar Dumas (Songs)], Kyiv: Vydavnychyi Dim „Komora”, 2018.

Krys'ko V., Social'naja psihologija: slovar'-spravochnik [Social Psychology: Reference Dictionary], Moskva: AST, 2001.

„Lysty tak dovho ydut...”: znadoby arkhivu Lesi Ukrainky v Slovianskii bibliotetsi u Prazi [,"Letters Go So Long..... Lesya Ukrainka's Archive Assets at the Slavonic Library in Prague”], uporiad., peredmova ta prym. S. Kocherha, Kyiv: Prosvita, 2003.

Selivanova O., Suchasna linhvistyka: terminolohichna entsyklopediia [Modern Linguistics: Terminology Encyclopedia], Poltava: Dovkillia, 2006.

Siletskyi Yu., Rosiiany v etnichnykh stereotypakh ukraintsiv (na materialakh ukrainskoho tradytsiinoho svitohliadu) [Russians in the Ukrainians' Ethnic Stereotypes (case study of the materials of the Ukrainian traditional philosophy)], [v:] „Naukovyi chasopys 
Natsionalnoho pedahohichnoho universytetu imeni M. P. Drahomanova. Seriia: Istorychni nauky", 2008, vyp. 6, s. 382-393.

Skidanova K., Etnichni stereotypy yak skladovi movnoi kartyny svitu [Ethnic Stereotypes as a Component of the Linguistic Picture of the World], [v:] „Naukovi zapysky Kirovohradskoho derzhavnoho pedahohichnoho universytetu imeni Volodymyra Vynnychenka. Seriia: Filolohichni nauky", 2009, vyp. 81(4), s. 27-31.

Slovnyk ukrainskoi movy [The Ukrainian Language Dictionay], v 11 tomakh, red. I.K. Bilodid, Kyiv: Naukova dumka, 1970-1980, t. 1-11.

Slovnyk ukrainskoi onomastychnoi terminolohii [Ukrainian Onomastic Terminology Dictionary], uklad. D. H. Buchko, N.V. Tkachova, Kharkiv: Ranok — NT, 2012.

Spohady pro Lesiu Ukrainku [Memories about Lesya Ukrainka], uklad. T. Skrypka, t. 1, Kyiv: Tempora, 2017.

Chaharyna S., Etnichni stereotypy v uiavlenni studentiv-ukraintsiv m. Lutska [Ethnic Stereotypes in the Interpretation of the Ukrainian Students in Lutsk], [v:] Elektronnyi resurs: https:// sp-sciences.io.ua/s2295702/chaharna_svitlana_2015._ethnic_stereo (01.07.2019).

Cheremska O., Maslo O., Linhvo-etnichni stereotypy ukrainskoi narodnoi kazky [Ukrainian Folk Tale: Linguo-Ethnic Stereotypes], [v:] „Kultura narodov Prychernomoria: nauchnыi zhurnal”, 2011, № 211, s. 113-115.

\section{Spysok vykorystanykh dzherel \\ [References]}

Lesia Ukrainka, Lysty: 1876-1897 [Letters: 1876-1897], uporiad. V. A. Prokip (Savchuk), peredmova V. P. Aheievoi, Kyiv: Komora, 2016.

Lesia Ukrainka, Lysty: 1898-1902 [Letters: 1898-1902], uporiad. V. A. Prokip (Savchuk), Kyiv: Komora, 2017.

Lesia Ukrainka, Lysty: 1903-1913 [Letters: 1903-1913], uporiad. V. A. Prokip (Savchuk), Kyiv: Komora, 2018. 